\title{
Increasing Organization Performance Through Competitive Advantage of Private University in Medan
}

\author{
Elizabeth Haloho \\ Department of Management \\ Faculty of Economic and Business \\ Universitas Sari Mutiara Indonesia \\ Medan, Indonesia \\ elisabeth.haloho@gmail.com
}

\author{
Lailan Tawila \\ Department of Management \\ Faculty of Economic and Business \\ Universitas Sari Mutiara Indonesia \\ Medan, Indonesia \\ lailan_tawila@yahoo.com
}

\begin{abstract}
There is increament number of students who finished Senior High School in Medan every year. With this reason, private universities are encourage to compete amongs them to atract new students to register. Therefore each of them must have a competitive advantage to become known by potential students and win the competition. This competitive advantage can be built with service differentiation and knowledge management. The purpose of the reasearch in longrun is to develop quality of education of Private Universities in Medan. The management of the institution will get important information to build Strategic Planning and Operational Planning of Higher Education Institutions. The competitive advantage of each Private university could be different one another but in this research will give insight on how using internal resources such as service differentiation and knowledge management will be benefitting the management. By maintaining their competitive advantage will increase the organization performance and will be shown by the result of National Accreditation Body of Higher Education in Indonesia ( BAN- PT).The research is located in Medan, North Sumatera, with 100 respondents than to choose Head of program studies from 11 universities in Medan. The criteria of universities in the research is universities with relative stabile and growing number of students each year. By using proportional Cluster Random sampling, the researcher will choose the respondent proportionally. The research will also be using Inferential in the data analysis. The analysis model is using path analysis by SPSS.
\end{abstract}

\author{
Keywords-service differentiation; knowledge \\ management; competitive advantage; \\ organizational performance
}

\section{INTRODUCTION}

Universities are the centers of higher education whereas the maintenance, and development of science, technology and / or arts in the hope of improving the quality of life in society, nation and country. The quality of education can be seen from the performance of University. Currently the quality of education in Indonesia is still relatively lower if compared to other countries in Southeast Asia. Based on a survey conducted by the Human Development Index (HDI) in 2014 that is used to measure the level of world education quality, Indonesia is ranked $108^{\text {th }}$, under Singapore on the rank of $9^{\text {th }}$, Malaysia with $56^{\text {th }}$ and Thailand at position $89^{\text {th }}$

The position of Indonesian universities at International level can also be seen from the list of the world's best universities issued by the Times Higher Education Supplement (THES). From the list issued by THES which was published in London in 2005 , there is no college of Indonesia who entered the top 100. In 2013, only the Universitas Indonesia and Institut Teknologi Bandung that entered the top 500 Best universities of the World with the rank of $309^{\text {th }}$ and $461^{\text {th }}$ (www.topuniversities.com)

The performance of universities in Indonesia can be seen as well from the ranking of Universities undertaken by the Ministry of Research and Technology of the Directorate of Higher Education (Kemenristekdikti) which conducted by an 
independent team established by Kemenristekdikti based on academic and nonacademic assessment in the year 2015. The rankings involving universities, both public and private, totaling 3244 institutions.

From the rankings, there is no university in North Sumatra is included in the top 10 ranking of the best Universities in Indonesia. Several universities in North Sumatera which ranked in the top 100 are Universitas Sumatera Utara (USU )ranked $38^{\text {th }}$, UNIMED ranked $29^{\text {th }}$ and Universitas Panca Budi at Rank $94^{\text {th }}$.

A research by Agha et al. [1] that stated Competitive Advantage could improve Organizational Performance. For the company to remain competitive and gain competitive advantage, managers can try to improve organizational performance by managing each of the core competencies dimensions of shared vision, cooperation and empowerment [9].

However, in managing competitive advantage,it must be done well to achieve superior performance. Hao Ma states that competitive advantage will not boost high performance if 1) a company that has competitive advantage but failed to develop it into a compound advantage, 2) the company failed to take advantage of that potential, 3) if it has some competitive advantage but failed to make the right combination, 4) the company deliberately sacrificed the competitive advantage [8]. Another study by Rita Mcgrath says that sustainable competitive advantage can not always be decisive in competition because of the effects of rapid development such as technology and market changes forcing competitive advantage must also change. The unique advantages which were difficult to imitate can not be sustained because of technological developments that eventually can be duplicated as well[16]

The pursuit of competitive advantage is arguable as a central theme in strategic management [20]. Strategic choices determine the markets in which organizations participate and where the organization positions are in those markets

Barney further suggests that a company has the potential to produce a competitive advantage. But it must have four attributes: (a) having values; (b) rare; (c) cannot be imitated and (d) there is no substitute[3]

There are several resources that can increase the competitive advantage such as service quality $[25,26]$, service differentiation $[13,19,21]$ knowledge management $[4,7,11,15,17]$. Therefore, this research will see the effect of service differentiation and knowledge management on competitive advantage and university Performance.

\section{THEORETICAL REVIEW}

The Correlation between service differentiation and competitive advantages

Differentiation is not only in physical products, the company can also differentiate its services. If the physical product is not easy to be differentiated, the key to success in competition lies in the addition of services that provide value added to the customer and improve the quality. This is the main differentiator between service companies. Vugt, creates various types of dimensions associated with differentiation and diversification of universities, namely:

- Structure: differences resulting from legal basis, policy, or history of college

- Program: difference of level and or type of program offered

- Reputation: Status and or prestige that is felt from certain institution

- Procedural: differences in teaching, research, and service functions in an institution

- Constituents: differences in student and staff background[27]

Differentiation strategy, cost leadership, quick response and market focus which were related to overall operating success refers to increasing competitive advantage [22]. The differentiation strategy also involves the company to create a product or service, which is considered unique in several aspects: Customer value to create competitive advantage [5]. The differentiation strategy is based on providing buyers with something different or unique, which makes the company's product or service different from its competitors. The differentiation of higher education is a direct and positive impact on the competitive advantage of these findings that differentiation is depicted regarding content, context, and structure that have value, a rare product, no substitute and not easily imitated by competitors [13].

\section{Correlation between Knowledge Management and competitive advantages}

According to Turban, et al. [24] Knowledge

Management is a process of helping corporate identity, selecting, organizing, disseminating, and sending vital information and expertise including parts of organizational memories that are typically located within the organization in the structured area.

From research, knowledge management is positively related to the success of an organization, especially in manufacture companies [6]. According 
to Probst et al., identification of knowledge is divided into three stages, namely :

- Structural knowledge: is a form of explicit knowledge and has been documented in hardcopy or digital form (softcopy). Structural knowledge in this company is things that are related to organizational structure such as job description and business process.

- Functional knowledge: aims to identify the existing knowledge in employees, namely through the job functions of each employee. Functional knowledge that is tacit must be documented, while explicit knowledge must be in the same application, making it easier for employees to access and use the knowledge to be implemented in the work process.

- Behavioral Knowledge: intended to identify ordinances in sharing or distributing knowledge from individuals to other employees, usually obtained through discussions among employees. Knowledge that is behavioral, usually has become a habit and become a culture in the company.

In achieving competitive advantage, knowledge management is important in assisting organizations in innovative product development. It is recommended that knowledge management to be used as an essential Business tool to gain competitive advantage and in turn, encourage economic growth [7]. Knowledge is seen as a strategic asset with the potential to be a source of competitive advantage for an organization. Knowledge management (KM) can be used to create a competitive advantage from RBV of company [8].

\section{Correlation between Competitive Advantages and Organization Performance}

The relationship between Competitive Advantages and Organizational Performance if incorporated into the theory according to Agha \&Alrubaiee (2012 )stated that to remain competitive and gain competitive advantage, managers can try to improve organizational performance by managing each dimension of shared vision core competencies; cooperation and empowerment. That competitive advantage (flexibility and responsiveness) positively affects organizational performance [10].

To achieve competitive advantage that can not only match their business rivals 'but also surpass the industry's average performance, business organization must first understand the relationship between internal strengths and weaknesses of their organizations, as well as the potential impact on their company's competitive advantage and performance

In other words, competitive advantage is considered as a part of the foundation for high-level performance. In the era of rapid technological advances and information systems, resources and product outsourcing, and globalization, company size will have little influence on the relationship between competitive advantage and organizational performance. Majeed.S [14] states that RBV is a firm competitive advantage and one of the keys of related strategic management theories, explaining the complex relationship between competitive advantage and company performance. The synchronization of middle management on competencies associated with higher performance is very important to oversee management to gain high performance. According to Al-Alak\&Tarabieh [2] in his research mentioned that managers identify the strategic orientations such as market orientation to enable companies to achieve competitive advantage and leading to greater organizational performance. Thus, to improve organizational performance, innovation, differentiation is relatively more important than focusing on market differentiation. In addition, it can also do both simultaneously to achieve a competitive advantage that leads to greater organizational performance.

\section{RESEARCH METHODOLOGY}

The research method used in this study is descriptive survey research method and explanatory survey method. The type of investigation used is causality,which is the type of research that states a causal relationship. The unit of analysis of this study is the Private University that operates in Medan city, while the observation unit is the Head of Study Program at private universities in Medan city. The research model that will be used as an analytical tool in this study is Partial Least Square-Path Modeling (PLS-PM).

Population and sample

The population of this research is the Head of Study Program registered at the private University in Medan City. Based on data from Kopertis Sumatera Utara, currently the number of private universities which were active in Medan is as many are 23 universities, but not all of the existing private universities will be the object of research. From the data obtained, private universities included in the criteria are 11 private universities located in Medan. Then to choose head of Program Studies at selected private universities, this research is using incidental 
sampling with a proportional number of as many as

\section{Result}

In this paper analyzing data was performed on two different parts. In the first part, indirect effect And the second part direct effect. The results obtained are explained below:

Table 1. Result of Significant Value SD, KM, and CA Variable

\begin{tabular}{|c|c|c|c|c|c|c|}
\hline \multirow[b]{2}{*}{ Model } & & \multicolumn{2}{|c|}{ Unstandardized Coefficients } & $\begin{array}{c}\text { Standardized } \\
\text { Coefficients }\end{array}$ & \multirow[b]{2}{*}{$t$} & \multirow[b]{2}{*}{ Sig. } \\
\hline & & $B$ & Std. Error & Beta & & \\
\hline \multirow[t]{4}{*}{1} & (Constant) & 13.233 & 5.436 & & 2.435 & .018 \\
\hline & Deferensiasi & .130 & .122 & .152 & 1.067 & .290 \\
\hline & Knowledge & 1119 & .042 & 299 & 2.855 & .006 \\
\hline & Keunggulan & .494 & .179 & .400 & 2.761 & .008 \\
\hline
\end{tabular}

Table 1 presents the results significant level. The results showed that the SD more than $0.05(0.290)$ and for each variable $\mathrm{KM}(0.006)$ and $\mathrm{CA}(0.008)$ was less than 0.05 .
100 respondent.

\section{A. Direct Effect}

The statistical results for direct effect Service Differentiation (SD),Knowledge Management (KM) and Competitive Advantage (CA)on Performace

\section{B. Indirect Effect}

Table 2. Result of Significant Value SD Variable and KM Variable

\begin{tabular}{|c|c|c|c|c|c|c|}
\hline \multirow[b]{2}{*}{ Model } & & \multicolumn{2}{|c|}{ Unstandardized Coefficients } & $\begin{array}{c}\text { Standardized } \\
\text { Coefficients }\end{array}$ & \multirow[b]{2}{*}{$\mathrm{t}$} & \multirow[b]{2}{*}{ Sig. } \\
\hline & & $B$ & Std. Error & Beta & & \\
\hline 1 & (Constant) & 21.540 & 2.745 & & 7.846 & .000 \\
\hline & $\begin{array}{l}\text { Deferensiasi } \\
\text { Knowledge }\end{array}$ & $\begin{array}{l}.484 \\
.064\end{array}$ & $\begin{array}{l}.062 \\
.029\end{array}$ & $\begin{array}{l}.699 \\
.198\end{array}$ & $\begin{array}{l}7.856 \\
2.224\end{array}$ & $\begin{array}{l}.000 \\
.030\end{array}$ \\
\hline
\end{tabular}

The results show that $\mathrm{SD}$ and $\mathrm{KM}$ variable positive related to Dependent variable of $\mathrm{CA}$, SD has the highest

effect with collaborative CA variable and its value is 0.699 . In other words, variance of SD variable can be
According to obtained results from measuring (CA) based on path analysis shows (SD) value is equal 0.00 and Knowledge Management (KM) value is less than 0.05 .

\section{The Figure of Path Analysis}

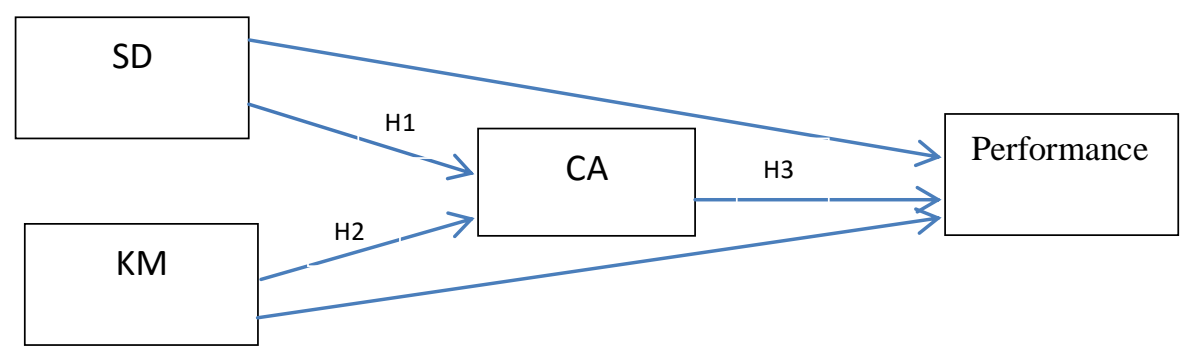

Figure 1. Path Analysis

Figure 1 presents the path analysis of the path model for the study. The path model indicates the evaluated by this overt variable. $\mathrm{KM}$ value is 0.98 has positively effect. The result of the study SD and KM have significant value $(<0.05)$ 
coefficients and the coefficient of determination. The

results of hypothesis finding:

Table 3. Results of Hypothesis Testing

\begin{tabular}{clccc}
\hline Hypothesis & Path Coefficient & Beta & Significant Level & Decision \\
\hline H1 & SD->CA & 0.690 & 0.000 & Supported \\
H2 & KM->CA & 0.198 & 0.030 & Supported \\
H3 & CA->Performance & 0.400 & 0.008 & Supported \\
H4 & SD-> Performance & 0.152 & 0.290 & Not supported \\
H5 & KM->Performance & 0.299 & 0.006 & Supported \\
H4 & SD->CA & $0.690 * 0.400=0.276$ & & Supported \\
& ->Performance & $0.198 * 0.400=0.079$ & & Supported \\
H5 & KM->CA & & & \\
& $->$ Performance & & &
\end{tabular}

\section{CONCLUSION}

This study aims to examine the influence of SD, $\mathrm{KM}$, and CA on Performance. The results generated from the path model indicate that $\mathrm{SD}, \mathrm{KM}$ has a significant influence on $\mathrm{CA}$ and $\mathrm{KM}, \mathrm{CA}$ have a significant influence on Performance, but SD have not significant influence on performance. Direct effect $\mathrm{KM}$ on performance has more value than indirect effect $\mathrm{KM}$ on performance with intervening variable CA. SD has not significant direct effect on performance, but SD influences performance with intervening variable $\mathrm{CA}$.

\section{REFERENCES}

[1] Agha, Sabah, Alrubaiee, LaithdanJamhour, Manar.(2012). Effect of Core Competence on Competitive Advantage and Organizational Performance.International Journal of Business and Management Vol. 7, No. 1.

[2] Al-alak, B.A., \&Tarabieh, S.A.. (2011). Gaining Competitive Advantage and Organizational Performance Through Customer Orientation, Innovation Differentiation and Market Differentiation. International Journal of Economics and Management Sciences, vol. 1 (5), pp 80-91.

[3] Barney, Jay, 1991," Firm Resources and Sustained Competitive Advantage," journal of management, Vol 17, No 1, 99-120

[4] Bractic, Diana, 2009, Knowledge And Knowledge Management As A Competitive Advantage, University of Zagreb, acta graphic 20(2009)1-4, 43-49

[5] Dirisu , Joy I, et 1, 2013, "Competitive Advantage And Optimal Organizational Performance (A Study Of Unilever Nigeria Plc"),Southern Cross University ePublications@SCU

[6] Gregory, Mark, Irena Decubes, Petr Mackovsky, 2010, Data, Information And Knowledge: A Candid And Pragmatic Discussion, 4th International Conference on
Advanced and Systematic Research, Zagreb,Croatia, Nov. 11th.-13th, 2010

[7] Gichuki, Michael,2014,Achieving Competitive Advantage ThroughKnowledge Management Practices By The Hotels InThe Coastal Region, Kenya, Theses, School Of Business, University Of Nairobi

[8] Halawi L, Aronson J and McCarthy R ,2005, "Resource-Based View of Knowledge Management for Competitive Advantage" The Electronic Journal of Knowledge Management Volume 3 Issue 2, pp 75-86

[9] Hao Ma, 2000, Competitive Advantage And Firm Performance, Article In Competitiveness, Review An International Business Journal Incorporating Journal Of Global Competitiveness Management Sciences Vol. 1, No. 5, 2011, pp. 80-91.

[10] Ismail, Alimin Ismadi, 2010, The Relationship Between Organisational Competitive Advantage And Performance Moderated By The Age And Size Of Firms, Asian Academy Of Management Journal Vol. 15, No. 2, 157-173

[11] Kaveh, Davood and Ehsan et al, 2015, The Relationship between Knowledge Management and Competitive Advantage: A Case Study in Small and Medium-Sized Companies in the Packaging Industry of Khorasan Razavi, Islamic Azad University,

[12] Kettunen, Juha, 2014, Competitive Strategies in Higher Education, Researchgate

[13] Kurniaty, Osman et al., 2015, Analysis Of Competitive Advantage Through Private High Education Service Quality And Differentiation, International Journal Of Research In Social Science

[14] Majeed.S. (2011).The Impact of Competitive Advantage on Organizational Performance.European Journal of Business and Management, 3 (4).

[15] Mahdi, Omar R, Mahmoud et al, 2011, The role of knowledge and knowledge management in sustaining competitive advantage within organizations: A review, African Journal of Business Management Vol. 5(23), pp. $9912-9931$ 
[16] Mcgarth, Rita, 2013, Modern Distribution Management, Vol. 43, No. 10 May, 2013

[17] Meihami, Bahram And Hussein Meihami, 2013, Knowledge Management A Way To Gain A CompetitiveAdvantage In Firms (Evidence Of ManufacturingCompanies), International Letters Of Social And Humanistic Sciences Online: 2013-1029ISSN: 2300-2697, Vol. 14, Pp 80-91

[18] Mucana, Burcu, EdaYaşaÖzeltürkayb*, 2014, "Social Media Creates Competitive Advantages: How Turkish Banks Use This Power? A Content Analysis of Turkish Banks through Their Webpages" Procedia - Social and Behavioral Sciences 148 ( 2014 ) 137 - 145

[19] Phenduka, Mamochele, 2015, Differentiation In Higher Education: A Case Study Of Lesotho, University Of Cape Town

[20] Porter, M. E. 1980. Competitive Strategy: Techniques for Analyzing Indstries and Competitors, The Free Press.

[21] Rahman, Md Shafiqur, 2011, Differentiation Of Services To Achieve Competitive Advantage: Airlines Meeting The Needs Of The Physically Challenged Persons, Theses, Southern Cross University
[22] Siriwan, Uthit, et.al, 2015, "The Management Of Small And Medium Enterprises to achieve Competitive Advantages In Northern Thailand 'European Scientific Journal December 2013 edition vol.9, No.34 ISSN: 1857 - 7881 (Print) e - ISSN 1857- 7431

[23] Tobari, 2015, Strategi Perguruan Tinggi Swasta Menghadapi Persaingan, Jurnal Wahana Ekonomika, Vol 12, No.3, Oktober 2015, 61-68

[24] Turban, Efraim\& Linda Volonino. 2010. Information Technology forManagement. EdisiKetujuh. Asia : John Willey \& Sons.

[25] Warraich Khalid Mehmood, Imtiaz Ahmad Warraich \& Muhammad Asif, 2013, Global Journal of Management and Business Research, Volume 13 Issue 2 Version 1.0, Online ISSN: 2249-4588 \& Print ISSN: 0975-5853

[26] Yeboah, Johnson dan George Dominic Ewur , 2014, Journal of Education and Practice, Vol.5, No.5, 2014, ISSN 2222-1735 (Paper) ISSN 2222-288X (Online)

[27] Vught, Frans van, 2007, Diversity and Differentiation In Higher Education Systems, CHET anniversary conferenceCape Town 